Portland State University

PDXScholar

Engineering and Technology Management

Student Projects

Engineering and Technology Management

Winter 2012

\title{
Application of Reference Models in Technology Management
}

Farshad Madani

Portland State University

Follow this and additional works at: https://pdxscholar.library.pdx.edu/etm_studentprojects

Part of the Other Operations Research, Systems Engineering and Industrial Engineering Commons, and the Technology and Innovation Commons

Let us know how access to this document benefits you.

Citation Details

Madani, Farshad, "Application of Reference Models in Technology Management" (2012). Engineering and Technology Management Student Projects. 1.

https://pdxscholar.library.pdx.edu/etm_studentprojects/1

This Project is brought to you for free and open access. It has been accepted for inclusion in Engineering and Technology Management Student Projects by an authorized administrator of PDXScholar. Please contact us if we can make this document more accessible: pdxscholar@pdx.edu. 


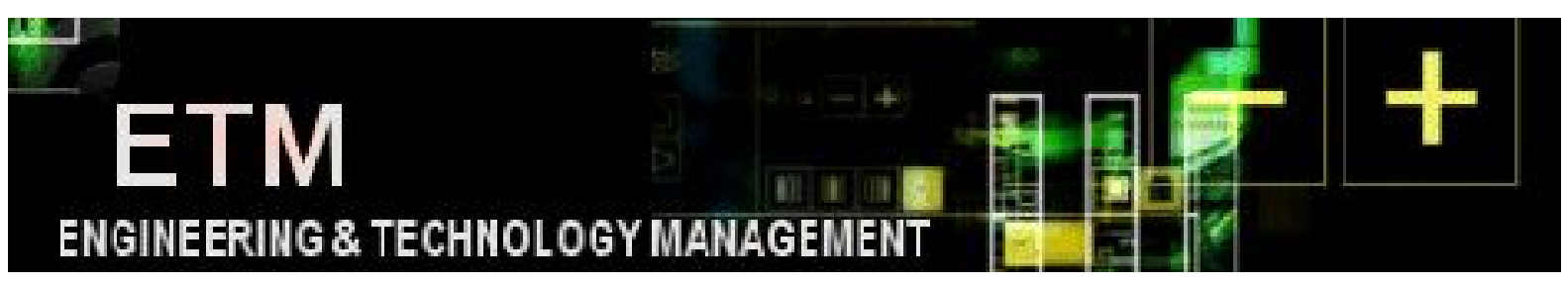

\section{Application of Reference Models in Technology Management}

Course Title: Research Methods in ETM

Course Number: EMGT 665

Instructor: Dr Timothy Anderson

Term: Winter

Year: 2012

Author(s): Farshad Madani 


\section{Contents}

Executive Summery 3

1- Introduction 4

2- What is a reference model? 6

3- Why are reference models needed in technology management? 8

4- History of using reference models in technology management 9

4-1- Technology management framework 9

4-2- A conceptual framework of technological innovation management 10

$\begin{array}{ll}\text { 4-3- Technology M anagement Assessment } & 10\end{array}$

4-4- Cambridge Manufacturing Leaders' Program Audit model 11

$\begin{array}{ll}\text { 4-5- Technology Selection Framework } & 13\end{array}$

5- Conclusion 13

$\begin{array}{ll}\text { 5-1- Summarization } & 13\end{array}$

$\begin{array}{ll}\text { 5-2- Suggestions for future studies } & 14\end{array}$

$\begin{array}{ll}\text { References } & 15\end{array}$ 


\section{Executive Summery}

Reference models, sometimes called with other different words, prepare a general model from a specific view of the related environment. Reference models are considered as a basic foundation to create: 1 ) a common language among specialists 2) a reference for the entities such as processes 3 ) relationships among entities 4 ) tools and decision making procedures for the real world.

In this report, it's tried the definitions of reference model in the selected papers have been reviewed. It's noticeable that in many papers the term of framework is used instead of reference model. Also, applications of reference models are reviewed and finally future studies are suggested. 


\section{1- Introduction}

Reference Model has been applied increasingly in various areas to cope with complexity. Information Technology, and Enterprise Architecture are the first areas which several versions of reference models are developed in. In addition, we can find several reference models developed in managerial areas.

Reference models are proportionally developed regarding to the problems supposed to be solved. Therefore, this assumption that reference models are going to solve all issues in the area at the same time is wrong, but reference models must be designed holistically to present all affecting variables on the problem in an integrated framework.

So far, many number of reference models are developed in various areas of management such supply chain management, information technology management, business management, and etc. For example, FEA ${ }^{1}$ is developed by US Federal Government to create a business driven model for entire Federal government. The FEA contains five consolidated reference models:

1. Performance Reference M odel (PRM)

2. Business Reference Model (BRM)

3. Service Component Reference Model (SRM)

4. Technical Reference Model (TRM)

5. Data Reference M odel (DRM)

As a sample we just point to two of above models.

1) The Federal Government Business Reference Model (FA BRM) provides an organized, hierarchical construct for describing the day-to-day business operations of the Federal government. The BRM, shown in Fig. 1, is the first layer of the Federal Enterprise Architecture and it is the main viewpoint for the analysis of data, service components and technology [1].

2) The PRM is a framework for performance measurement providing common output measurements throughout the federal government. It allows agencies to better manage the business of government at a strategic level, by providing a means for using an agency's EA to measure the success of IT investments and their impact on strategic outcomes [1].

In addition to FEA, we can refer to two famous reference models which have applied widely in international level:

- SCOR: a process reference models developed for supply chain management

- PMBOK: a comprehensive reference model for project management

The successful promotion of these reference models inspires that technology management area potentially needs to have such reference models. We will discuss more about the need of developing reference models in technology management.

1 - Federal Enterprise Architecture 


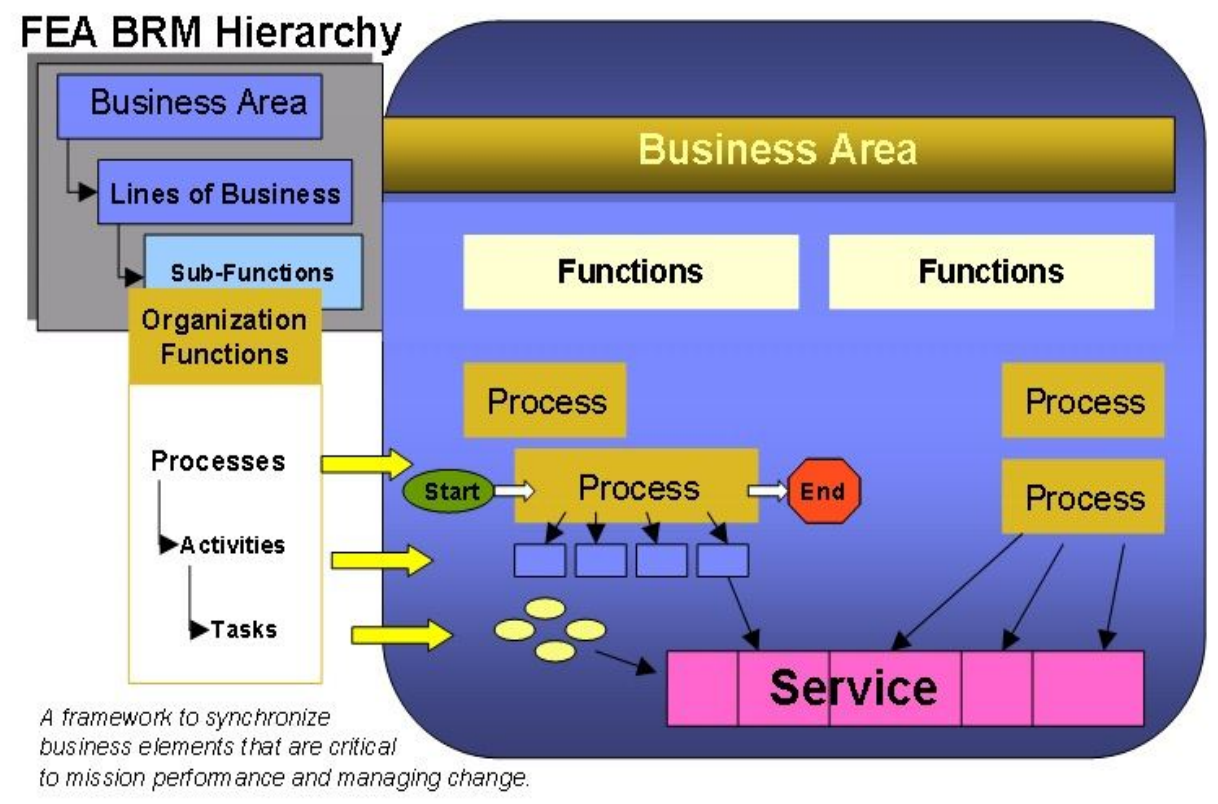

Figure 1- FA Business Reference M odel [1]

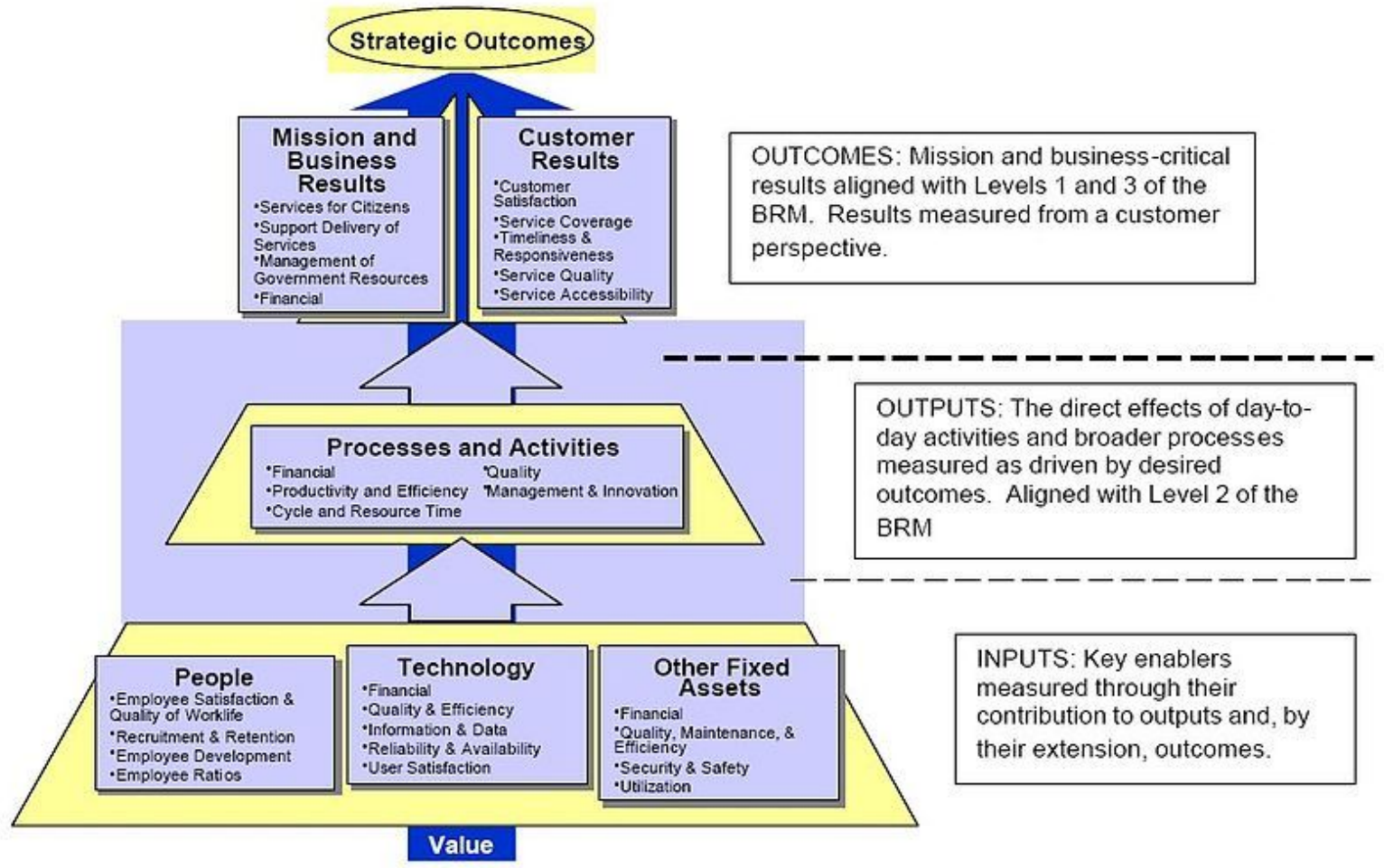

Figure 2- FA Performance Reference M odel [1] 


\section{2- What is a reference model?}

A reference model is an abstract framework for understanding relationships among the entities of some environment. Usually, based on a reference model, standards are developed to support the environment. Unifying concepts is a key point in developing reference models.

The term of "reference model" has not been used exactly in studies. Terms including "framework", "architecture", "enterprise", and "system" are used each alone or in combination to others.

Bernus and Names used and defined the term of "Architecture" as below[2]:

"This is the definition of enterprise related concepts, with the primary focus on the life cycle of the enterprise. Since the life cycle can be considered as a design process the architecture will also have to identify the results and the intermediary components of this design process."

Also they introduced Generic Enterprise Engineering M ethodology as below [2]:

"This is the description, on a general level, of the processes of enterprise integration. In other words the methodology is a detailed process-model, with instructions for each step of the integration process."

Phaal and his coworkers have used "framework" term and defined [3]:

- The framework, which is consistent with concepts from resource- based and systems thinking, provides a bridge between theory and practice[3][3][3][3][3][3].

- Conceptual frameworks in management theory and practice support understanding of an issue or area of study, provide structure and support decision making and action.

- The overall aim of the framework is to support understanding of how technological and commercial knowledge combine to support strategy, innovation and operational processes in the firm, in the context of both the internal and external environment.

According to this definition, Phaal and his colleagues have developed a meta-framework structuring relationships between two key dimensions "applied- conceptual" and 'static-dynamic". They defined these quadruplet terms [2]:

- Conceptual: concerned with the abstraction or understanding of a situation

- Applied: concerned with concrete action in a practical environment

- Static: concerned with the structure and position of elements within a system

- Dynamic: concerned with causality and interaction between the elements of a system. 


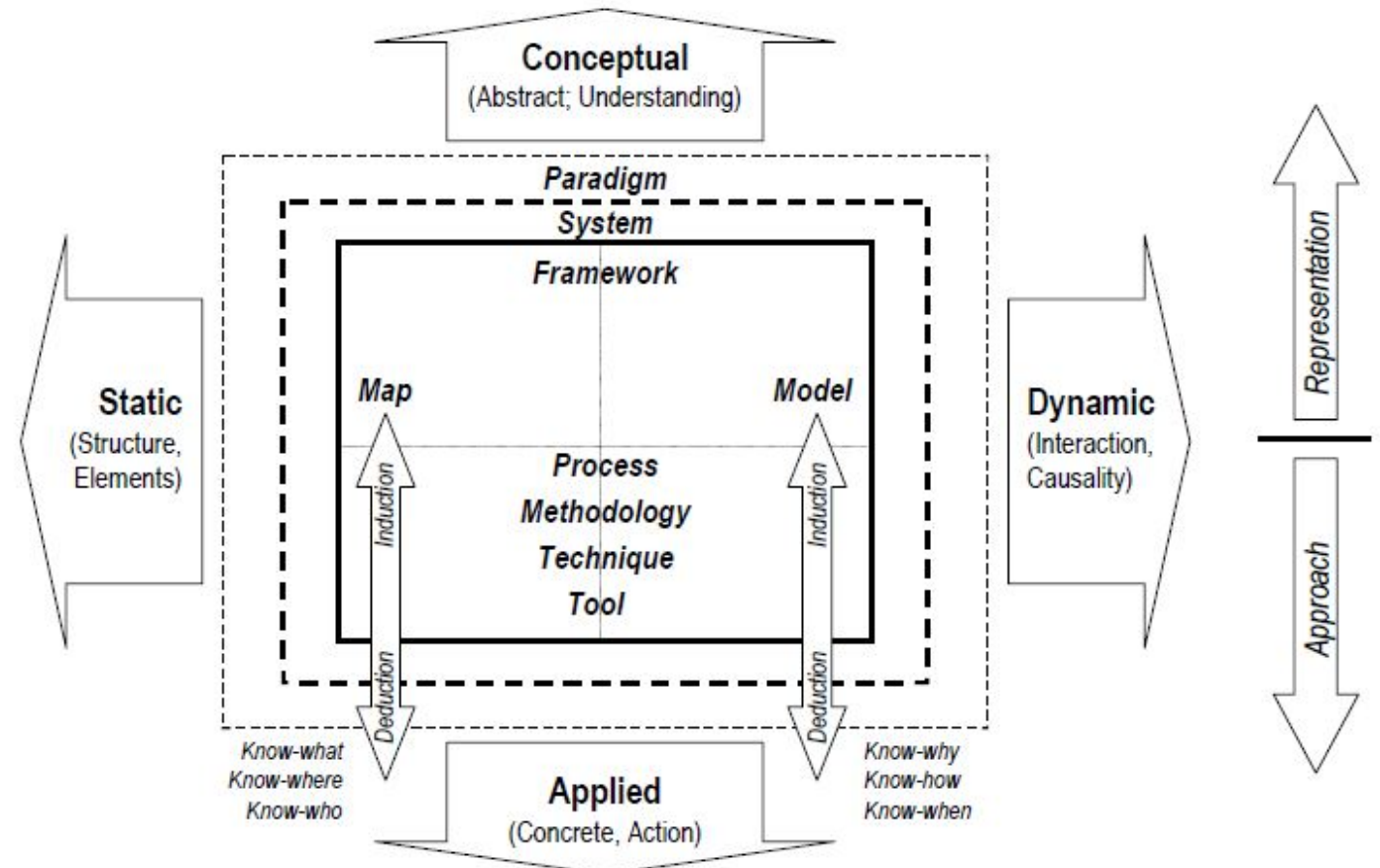

Figure 3- Meta-framework: management representations and approaches[3]

Phaal and his coworkers defined all main terms in their conceptual model, meta-framework [3]:

- a paradigm describes the established assumptions and conventions that underpin a particular perspective on a management issue

- a system defines a set of bounded interrelated elements and represents it within the context of a paradigm

- a framework supports understanding and communication of structure and relationship within a system for a defined purpose

- a map supports understanding of the static relationship between elements of a system Deduction Induction Deduction Induction Approach Representation

- a model supports understanding of the dynamic interaction between the elements of a system

- a process is an approach for achieving a managerial objective, through the transformation of inputs into outputs

- a procedure is a series of steps for operationalising a process

- a technique is a structured way of completing part of a procedure

- a tool facilitates the practical application of a technique

The scholars through this conceptual framework make a bridge between theories and practical environment by developing devices such as methods, processes, techniques and tools.

In another study Phaal incorporation with Shehabuddin, and Probert pointed "framework" supports the understanding and communication of structure and relationship within a system for a defined purpose [4]. 


\section{3- Why are reference models needed in technology management?}

In various studies, scholars point different reasons about needs to application of reference models in technology management. In continue, it's pointed to some studies.

Technology Management like many areas in management science needs reference model because technology management inherently is created from processes. In relevant to this subject, the National Research Council's (NRC) definition in 1987 puts a clear emphasis on understanding TM as a process, which can be conceptualized as an approach to achieving a managerial objective, through the transformation of inputs into outputs[5].

Using reference models in other areas such as business management has several advantages. First, they significantly speed up the design of business process models by providing reusable and high quality content. Secondly, reference models lead to better and optimized process designs as they have been developed over a longer period and usually capture the business insight of more than one industry player. Thirdly, the reference model content usually bridges the business and the IT domain[6].

J. T. Chiang argues that studies in technological innovation management are not mature enough in terms of (I) the conceptual categories, (2) the interrelationships and (3) the taxonomy of relevant systems[7] .

We lack a usable conceptual framework of technological innovation management. Without the framework, we lack a common ground to discuss the matter, and hence we may emphasize ignore very important some topics unnecessarily, topics unwittingly, and may even be unable to agree on what to teach in courses on technological innovation management [7].

Effective technology management requires the integration of technical, marketing, human resource, and financial functions. In addition, it is essential for strategic management and operational processes to be integrated [8].

Technology management is a multifunctional and multidisciplinary field, requiring inputs from both commercial and technical functions in the firm and a synthesis of academic perspectives, such as engineering, economics, business studies, social science and psychology. As yet there are very few widely adopted methods for the practical application of technology management principles, and few universally accepted conceptual models or frameworks to underpin them [3].

Examination of these definitions highlights a number of factors that characterize technology, which can be considered as a specific type of knowledge (although this knowledge may be embodied within a physical artifact, such as a machine, component, system or product). The key characteristic of technology that distinguishes it from more general knowledge types is that it is applied, focusing on the 'know-how' of the organization. Whilst technology is often associated with science and engineering ('hard' technology), the processes and infrastructure that enable its effective application are also important [3].

Even though there are a number of TM handbooks, they do not offer any clear set of TM activities and in fact, many of them result in confusion on what technology managers need to do, since their 
coverage consists of numerous managerial tasks that are very general and have no explicit link to specific TM concepts (Dorf, 1999)[5].

\section{4- History of using reference models in technology management}

Although technology management is a young area, and there is no many researches using reference models, we can several studies about this subject. Among universities, University of Cambridge has the most studies about application reference models in technology management. Even this university has established "Center for Technology Management" in Institute for Manufacturing" (IfM ). Georgy, Phaal, Farrukh, and Probert are scholar working on application of reference models in technology management in Cambridge. They have published several books and papers some of which are referred in this report. Also, they have accomplished several projects by developing reference models and creating related tools in several parts of technology management including technology and strategic roadmapping, technology intelligence, portfolio management, etc. In continue, some important researches are introduced.

\section{4-1- Technology M anagement Framework}

The most comprehensive framework developed in technology management is "Technology Management Framework" presented in Fig. 2. In this framework TM activities (identification, selection, acquisition, exploitation and protection of technology) are typically linked to or embedded within core business processes (Phaal et al., 2004): strategy, innovation and operations. For instance, technology selection decisions are made during business strategy and new product development[5].

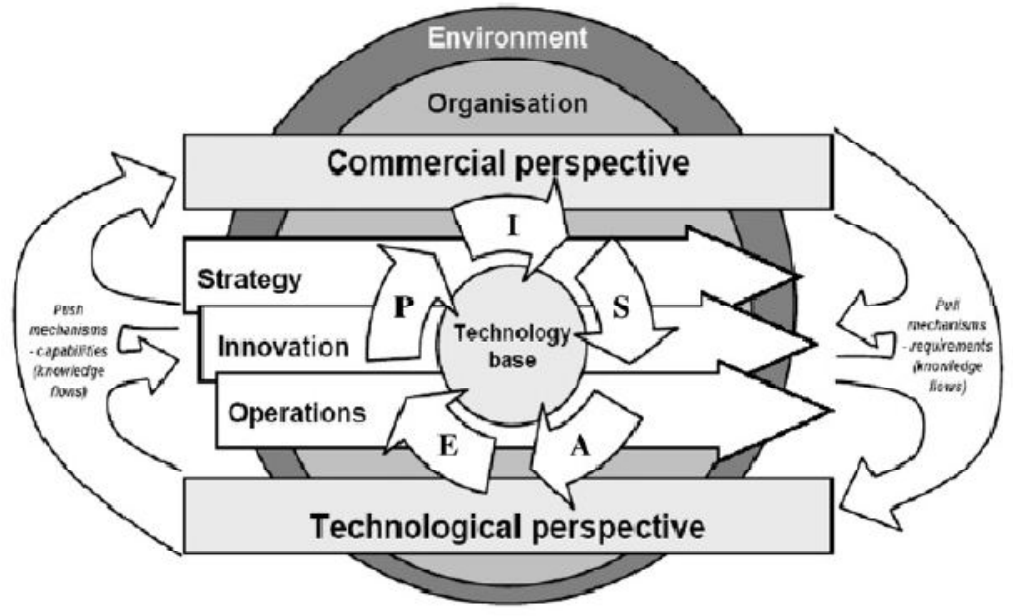

Figure 4- Technology M anagement Framework

This framework helps to understand well how technological processes and business processes are related to support strategy and how they are interacted with both environment and organization. Five technological processes are [3]:

- Identification of technologies that are not currently part of the firm's technology base, but may be important in the future (for example, by attending conferences, reading journals, visiting trade fairs, questioning suppliers and conducting pure research) 
- Selection of those technologies that the firm needs for its future products and technologies (for example, by using portfolio-type methods, expert judgment, pilot studies and financial methods).

- Acquisition of the technologies that have been selected (for example, by $R \& D$, licensing, purchase of equipment, hiring of staff and acquisition of firms)

- Exploitation of the technologies that have been acquired (for example, by incorporating into products and services and licensing)

- Protection of the technological assets of the firm (for example, by legal means such as patenting, contracts, trademarks, copyright, together with security measures and retention of key staff).

Business processes are strategy, innovation, and operation. The aim of effective technology management is to ensure that technological issues are incorporated appropriately into these processes, to form a technology management system that is coherent and integrated across and beyond specific business processes and activities [3]. To link technological and commercial perspectives, required mechanisms like cross functional teams, management tools, and etc are prepared in the framework. In addition, Time is a key point predicted implicitly in SIO and ISAEP processes in the framework. This framework has been used in many technological management issues practically such as [3]:

- process for supporting strategic make-or-buy decisions in manufacturing

- portfolio-based method for $R \& D$ project evaluation

- procedure for assessing technology management processes in business

- process for initiating technology roadmapping in firms

- tool catalogue for supporting technology managers in business

\section{4-2- A conceptual framework of technological innovation management}

In this study, researchers have used the model of Hellriegel, J.W. Slocum, Jr. and R.W. Woodman, a general framework for organizational changes. Because the categories and interrelationships should not be different from technology management area, the researchers have customized Hellriegel's model for technology management. They considered financial and administrative systems, people, structure, and strategy in addition to technological core processes comprising technology selection, technology acquirement, and technology exploitation.

The proposed framework of technological innovation management consists of the same five categories as in Hellriegel's model [7].

\section{4-3- Technology Management Assessment}

This study has not a holistic view on technology management. On the other word, the scholars have just focused on a part of technology management, assessment process. Since this study is done by Cambridge's scholar mentioned before, we'd better say this research is in the continuance of "technology management framework". In fact they pointed in their paper to this framework. 
Table 1- The conceptual framework of technological innovation management [7]

\begin{tabular}{|l|c|}
\hline Category 1. People & Authority structure \\
Best R\&D members & Role structure \\
Education and Training & Conflict resolution \\
& Communication management \\
Category 2. Task & \\
System management & Category 5. Strategy \\
System engineering & Technology selection \\
Configuration management & Target technology area \\
Program management & Scope of R\&D \\
Value Engineering & Phased planning \\
Computing Services & Technology acquisition \\
& Technology external technologies \\
Category 3. Technology & Valuable external acquisition \\
Project specific & Internalization \\
& Technology exploitation \\
Category 4. Structure & Collaborative systems \\
Innovative organization form & Competitive systems \\
Decision-making mode and speed & Roles of participation \\
& \\
\hline
\end{tabular}

The technology management process assessment procedure comprises three main stages (see Fig. 3) described in detail in subsequent sections [8]:

1- The Strategic Overview defines a framework for linking technology with business objectives, and enables selection of area/s for more detailed appraisal.

2- The Process Overview focuses on the business- technology area/s selected in stage 1, mapping and assessing technology management activities in terms of the five-process framework (Fig. 1), leading to the identification of specific processes for more detailed assessment.

3- The Process Investigation focuses on mapping and assessment of specific process areas identified during stage 2 .

In this study, researchers have proceeded more deeply in as much as they have developed a procedure to make assessment in above triple stage. In addition, they have applied it in wide range of organizations, in terms of size and industrial sector.

\section{4-4- Cambridge Manufacturing Leaders' Program Audit model}

This study is one of Cambridge's researches which are extended based on Technology Management Framework. The manufacturing business systems model that has been adopted is that used by the University of Cambridge Manufacturing Leaders Program (MLP), which forms the basis for a company audit - see Figure 4. The M LP model is built up in three stages (or levels)[3]:

- Level 1: a simple resource-based process view, where resources are identified as comprising people and facilities, which are combined with operational processes to transform inputs into required outputs. Based on the discussions above, the technology base of the firm can be considered to be a sub-set of these resources and processes. 


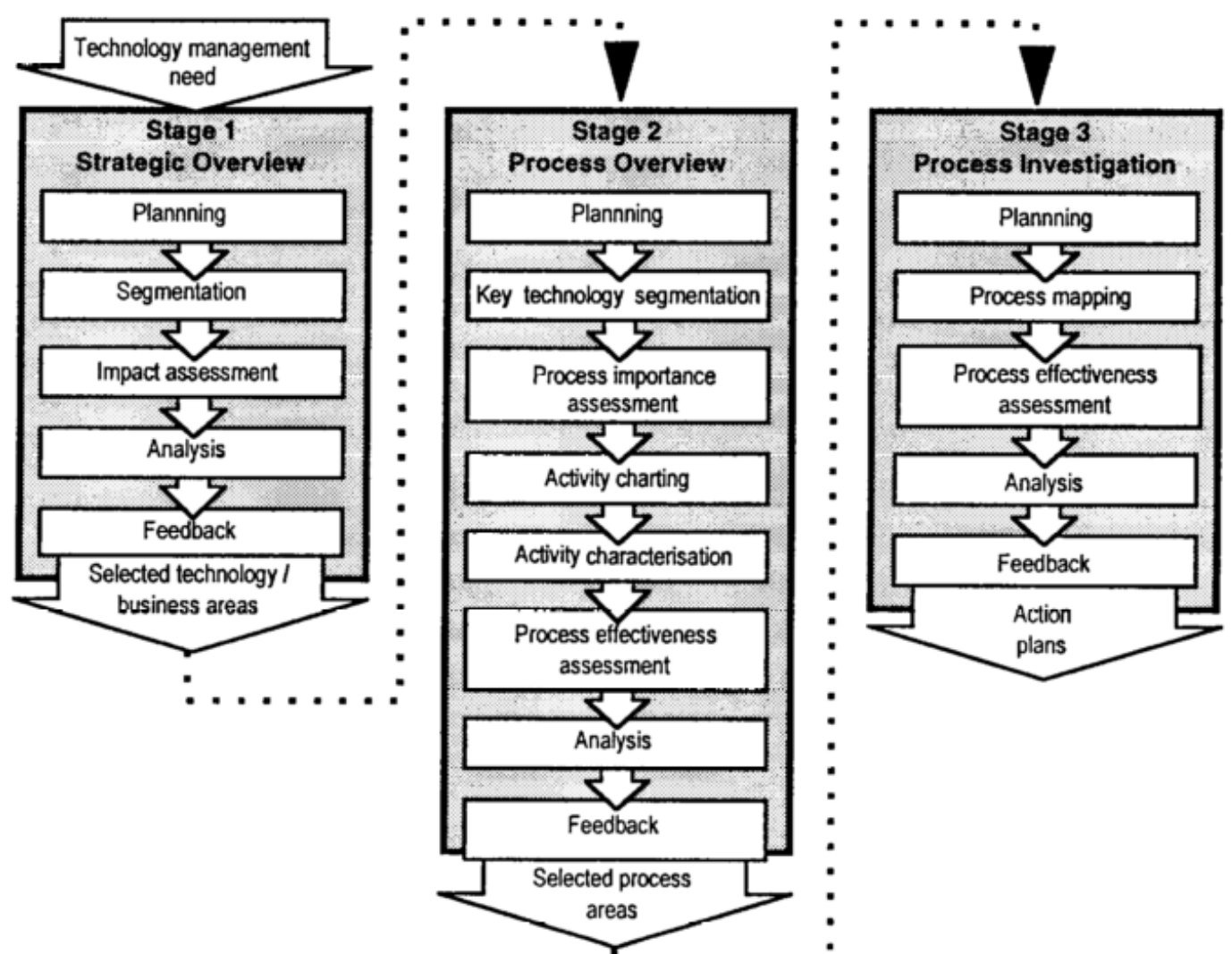

Figure 5. Technology management assessment process procedure

- Level 2: expansion of the model to the firm level, defining the manufacturing business, in the context of the value chain that links suppliers to customers, highlighting a number of important business processes. These processes are strategy development, supply chain management and new product introduction, supplemented by supplier and customer development processes.

- Level 3: expansion of the model to include the business environment in which the firm operates: industry sectors, competitors and suppliers, current available technology, customers / consumers and liability, environment and economy. The broader trends that govern the evolution of this business environment are included in the model (such as industry trends, technology trends, general societal trends and political and economic trends).

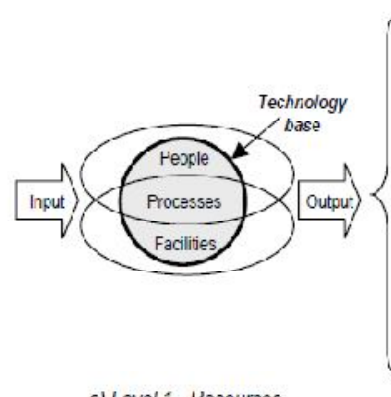

a) Level 1 - Resources

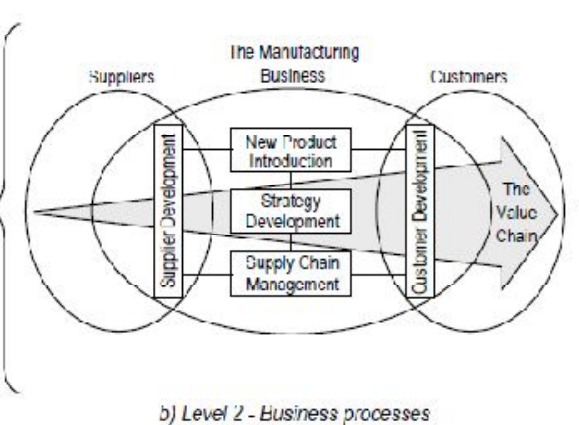

b) Level 2 - Husiness processes

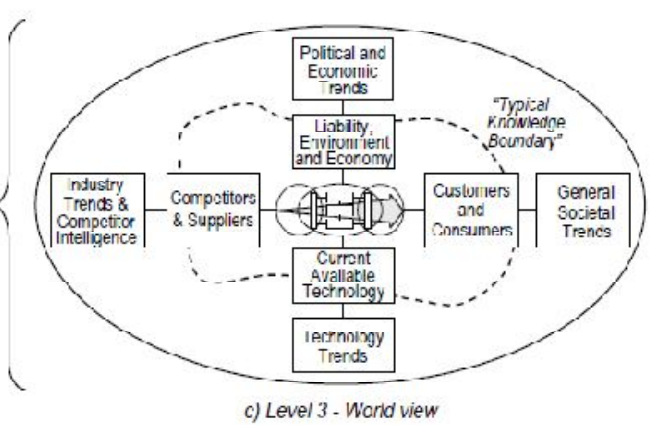

c) Level 3 - World view

Figure 6. Cambridge Manufacturing Leaders' Program Audit model [3] 


\section{4-5- Technology Selection Framework}

It's another study by Cambridge's scholars who have developed a framework theoretically and have applied practically in technology selection. To deploy the framework, they have developed software based on the framework shown in the Fig. 5 . The framework contains all phases in selection process and all main factors are determined in each phase. All affecting internal and external entities are considered in the framework.

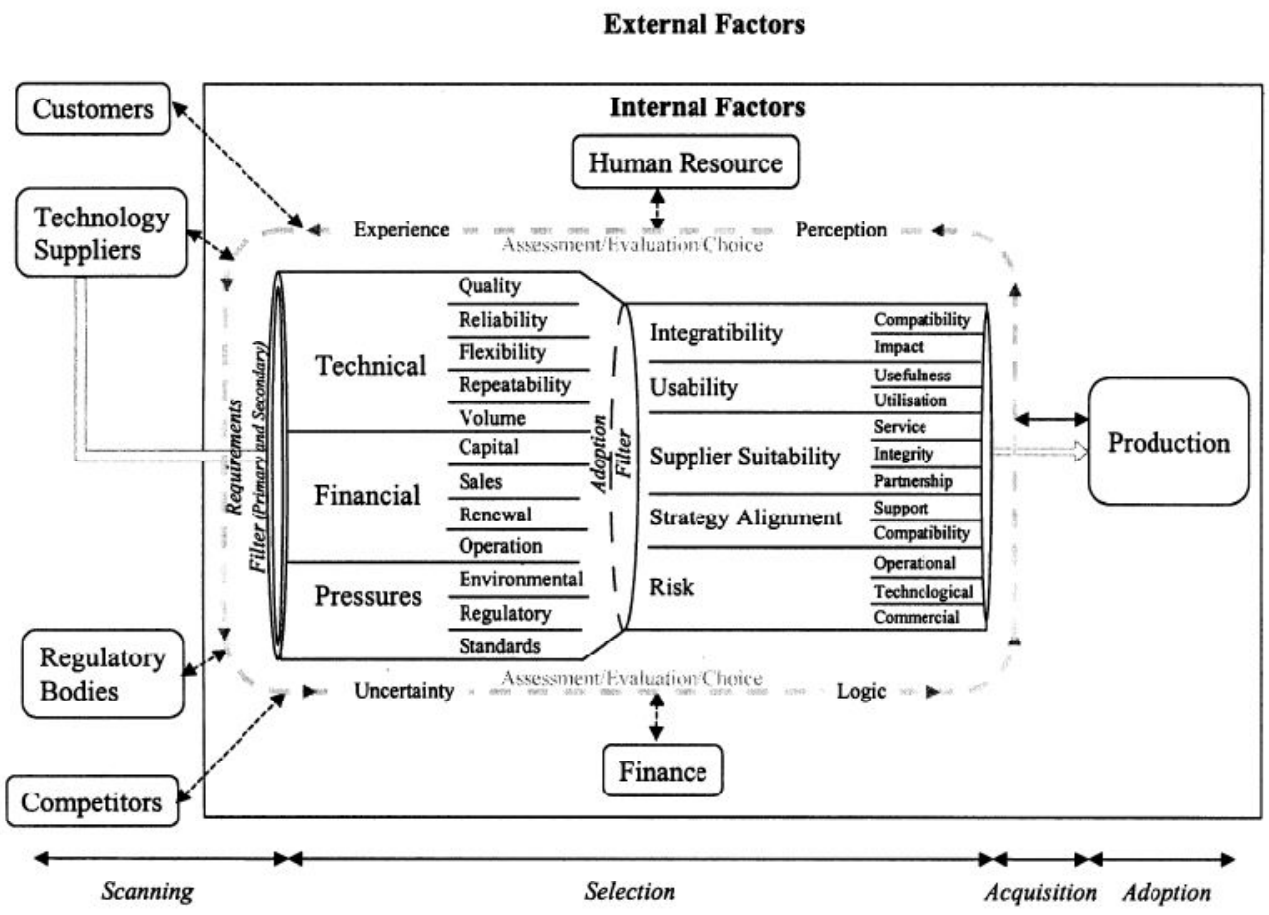

Figure 7- The technology selection framework [4]

\section{5- Conclusion}

\section{5-1- Summarization}

The main reasons for developing reference model in technology management are:

- Technology management is not mature enough in terms of (I) the conceptual categories, (2) the interrelationships and (3) the taxonomy of relevant systems [7]

- Effective technology management requires the integration of technical, marketing, human resource, and financial functions [8]

- Technology management is a multifunctional and multidisciplinary field, requiring inputs from both commercial and technical functions in the firm and a synthesis of academic perspectives, such as engineering, economics, business studies, social science and psychology. As yet there are very few widely adopted methods for the practical application of technology management principles, and few universally accepted conceptual models or frameworks to underpin them [3]. 
Some of the researchers studied in this report have holistic view, and some focus on a specific part or process of technology management. Some have a broad view on internal/external factors, and some just concentrate on some group of factors. Some have not implemented in the real world, and some have applied practically. There is a brief view of the studies review in table 2 .

\begin{tabular}{|c|c|c|c|c|}
\hline Name & Main Processes & $\begin{array}{l}\text { Internal } \\
\text { Factors }\end{array}$ & $\begin{array}{l}\text { External } \\
\text { Factors }\end{array}$ & $\begin{array}{c}\text { Applied } \\
\text { practically }\end{array}$ \\
\hline $\begin{array}{l}\text { Technology } \\
\text { management } \\
\text { framework }\end{array}$ & $\begin{array}{l}\text { Identification, } \\
\text { selection, acquisition, } \\
\text { exploitation, } \\
\text { protection }\end{array}$ & $\begin{array}{l}\text { Core business } \\
\text { processes } \\
\text { including } \\
\text { strategy, } \\
\text { innovation, and } \\
\text { operations }\end{array}$ & $\begin{array}{l}\text { Commercial and } \\
\text { technological } \\
\text { perspectives }\end{array}$ & Yes \\
\hline $\begin{array}{l}\text { conceptual } \\
\text { framework of } \\
\text { technological } \\
\text { innovation } \\
\text { management }\end{array}$ & $\begin{array}{l}\text { Selection, } \\
\text { acquisition, and } \\
\text { exploitation in } \\
\text { strategy category }\end{array}$ & $\begin{array}{l}\text { People, task, } \\
\text { technology, and } \\
\text { structure }\end{array}$ & none & No \\
\hline $\begin{array}{l}\text { Technology } \\
\text { Management } \\
\text { Assessment }\end{array}$ & $\begin{array}{l}\text { Assessment all } \\
\text { technological } \\
\text { processes } \\
\text { (Identification, } \\
\text { selection, acquisition, } \\
\text { exploitation, } \\
\text { protection) }\end{array}$ & $\begin{array}{l}\text { Focuses on } \\
\text { processes }\end{array}$ & $\begin{array}{l}\text { Focuses on } \\
\text { technological } \\
\text { business segments }\end{array}$ & Yes \\
\hline $\begin{array}{l}\text { Cambridge } \\
\text { Manufacturing } \\
\text { Leaders' Program } \\
\text { Audit model }\end{array}$ & $\begin{array}{l}\text { Level 2: Business } \\
\text { Processes (New } \\
\text { Product Introduction, } \\
\text { Strategy Development, } \\
\text { Supply Chain } \\
\text { Management) }\end{array}$ & $\begin{array}{l}\text { Level 1: } \\
\text { Resources } \\
\text { (People, } \\
\text { processes, } \\
\text { facilities) }\end{array}$ & $\begin{array}{l}\text { Level 3:World } \\
\text { View (Political and } \\
\text { Economical trends, } \\
\text { Technology trends, } \\
\text { General social trends, } \\
\text { Industry trends) }\end{array}$ & Yes \\
\hline $\begin{array}{l}\text { Technology } \\
\text { Selection } \\
\text { Framework }\end{array}$ & $\begin{array}{l}\text { Selection (and } \\
\text { relevant processes: } \\
\text { scanning, acquisition, } \\
\text { adoption) }\end{array}$ & $\begin{array}{l}\text { Production, } \\
\text { Finance, } \\
\text { Human } \\
\text { Resource, }\end{array}$ & $\begin{array}{l}\text { Customers, } \\
\text { Technology } \\
\text { Suppliers, } \\
\text { Regulatory Bodies, } \\
\text { Competitors }\end{array}$ & Yes \\
\hline
\end{tabular}

Table 2. A brief view of studies reviewed

\section{5-2- Suggestions for future studies}

- There are many researches missed in this report due to lack of time. Doing a comprehensive research to find all papers in conferences and journals is necessary to find gaps in them.

- Benchmarking between reference models in technology management and reference models in other areas can give some useful guidance because management in technology area has many common features with management in other areas.

- Developing a framework considering more detailed processes would help to find a more comprehensive reference model for technology management.

- Developing appropriate tools for decision making in

- Managing of technology in industry level, and even in national level have their own processes. Developing related frameworks would be useful to create an integrated framework.

- Considering life cycle of organizations in framework can cause advice more effectively.

- Considering the size of organization helps to customize frameworks and to avoid irrelevant aspects and factors. 


\section{References:}

[1] "FEA Consolidated Reference M odel Document," October, no. October. 2007.

[2] P. Bernus, "A Framework to Define a Generic Enterprise Reference Architecture and $M$ ethodology Introduction: Identi cation of what is a Generic Enterprise Reference Architecture and M ethodology," Engineering.

[3] R. Phaal, C. J. P. Farrukh, and D. R. Probert, "A framework for supporting the management of technological knowledge," International Journal of Technology Management, vol. 27, no. 1, p. $1,2004$.

[4] N. Shehabuddeen, D. Probert, and R. Phaal, "From theory to practice: challenges in operationalising a technology selection framework," Technovation, vol. 26, no. 3, pp. 324335, Mar. 2006.

[5] D. Cetindamar, R. Phaal, and D. Probert, "Understanding technology management as a dynamic capability: A framew ork for technology management activities," Technovation, vol. 29, no. 4, pp. 237-246, Apr. 2009.

[6] J. Koehler and K. Ryndina, "Improving Business Process Models with Reference Models in Business-Driven Development," pp. 35-44, 2006.

[7] M. Lee and K. Om, "A conceptual framework of technological management," Technovation, vol. 14, no. 1, pp. 7-16, 1994.

[8] R. Phaal, C. J. Paterson, and D. R. Probert, "Technology management in manufacturing business: process and practical assessment," Technovation, vol. 18, no. 8-9, pp. 541-589, Aug. 1998.

[9] T. Brady, H. Rush, M. Hobday, a. Davies, D. Probert, and S. Banerjee, "Tools for technology management: An academic perspective,"Technovation, vol. 17, no. 8, pp. 417-426, Aug. 1997.

[10] C. Farrukh, P. Fraser, D. Ahjidakis, R. Phaal, D. Probert, and D. Tainsh, “Developing An Integrated Technology M anagement Process," Research Technology M anagement.

[11] P. Fettke and P. Loos, "Classification of reference models: a methodology and its application," Information Systems and e-Business M anagement, vol. 1, no. 1, pp. 35-53, Jan. 2003.

[12] M. Gerosa and M. Taisch, "A novel Industrial Services Reference M odel," Business.

[13] D. M ayrhofer, “Reference Modeling for Inter-organizational Systems," Process Technology.

[14] R. Phaal, C. J. P. Farrukh, and D. R. Probert, "Technology management tools: concept, development and application," Technovation, vol. 26, no. 3, pp. 336-344, Mar. 2006.

[15] R. Phaal, C. J. P. Farrukh, and D. R. Probert, "Technology roadmapping-A planning framework for evolution and revolution," Technological Forecasting and Social Change, vol. 71, no. 1-2, pp. 5-26, Jan. 2004. 